\title{
CRADLE TO CRADLE REGENERATIVE DESIGN: FROM CIRCULAR ECONOMY TO SUSTAINABLE CONSTRUCTION
}

\author{
ALEXANDROS KITRINIARIS ${ }^{1,2}$ \\ ${ }^{1} \mathrm{KAAF}$ - Kitriniaris Associates Architecture Firm, Greece \\ ${ }^{2}$ School of Architecture, National Technical University of Athens, Greece
}

\begin{abstract}
It is estimated that the world's population will reach 9.7 billion by 2050 . The population growth is leading to an increased production of goods and the multiplication of waste, while simultaneously depleting the earth's resources. The purpose of this paper is to show that the only solution to combine production efficiency with a healthier environment is to adopt cradle to cradle regenerative design processes by using renewable energy sources. The increasing global production of sewage sludge from wastewater treatment plants has raised critical questions regarding the most efficient environmental and economic methods of managing the final product. Europe produces an average of 13 million tonnes of sludge dry solids annually. It is estimated that approximately 1.7 million tonnes of Sewage Sludge Ash are produced annually world-wide and this is likely to increase in the future. SSA can be used as a raw material in the construction field. To this end, we are attempting to present our internationally awarded project "Earthwood", which adopts cradle to cradle regenerative design processes as it uses renewable energy sources including sewage sludge produced by Wastewater Treatment Plants, lightweight aggregates and cement or lime generated by cement factories and structural timber fabricated by wood industries. "Earthwood" integrates sustainable construction technology with traditional building design methods. It can be constructed in a limited timetable, i.e. 2-4 days; is self-sufficient through solar energy and sound water management; is composed of recyclable construction materials including sewage sludge ash stabilized rammed earth and structural cross laminated timber, while simultaneously promoting social responsibility and economic viability, improving living conditions, minimizing its ecological footprint and ensuring an enduring positive impact on communities and on the environment. Keywords: sustainability and the built environment, environmental management, resources management, waste management, sewage sludge, cradle to cradle, circular economy, rammed earth, cross laminated timber, recyclability and ecological awareness.
\end{abstract}

\section{INTRODUCTION}

The central thread of this paper connects the reproductive process of design with circular economy, environmental management, and waste management aiming to produce sustainable buildings and landscapes. These concepts comprise a deeper object of study of the author and are closely connected to both his professional and his academic areas of activity. However, for this narrative to be more immediately understood, it will be illustrated through our recent award-winning project for a self-sufficient sustainable house in Salamis island, which is committed to the triple bottom line concept, which asserts that long-term and sustainable progress requires the balanced achievement of economic development, environmental performance, and social advancement. To this end, the narrative above will be developed on the global, regional, and local scale of the ecosystemic approach though cradle to cradle regenerative design processes.

\section{GLOBAL SCALE}

It is estimated that the world's population will reach 9.7 billion by 2050 [1]. The population growth is leading to an increased production of goods and the multiplication of waste, while simultaneously the earth's resources are being depleted. It seems that the only solution to 
combine production efficiency with a healthier environment is to adopt cradle to cradle regenerative design processes by using renewable energy sources.

\subsection{Existing production model}

The rapid increase in population is leading to a constant increase in product manufacturing to meet biological and technical needs, which in turn leads to increased waste production, while at the same time, natural resources appear to be constantly diminishing.

\subsection{Recyclable production model}

A possible initial solution could be to reduce product manufacturing to minimize the exhaustion of natural resources. In this case, waste products are recycled to manufacture new products; however, in the long term, resources would continue to be depleted at a slower rate in relation to the previous production model.

\subsection{Cradle to cradle production model}

We therefore recommend a more effective production process in combination with a healthier environment by adopting circular reproductive design processes and the exclusive use of renewable energy sources. In this case, harmless component ingredients are used to manufacture products, while waste is reused within the system, either as biological or as technical resources [2].

\subsection{Circular economy model}

The two production cycles, that is, the biological and the technical, complement and interact with each other with the aim of producing improved and more effective products. Consumption of the resulting products lies at the intersection of the two cycles, since every time it is the starting point for a new flow within the overall ecosystemic perspective [3].

\section{REGIONAL SCALE}

Europe produces an average of 13 million tonnes, while Greece produces an average of 300,000 tonnes of sludge dry solids annually. The increasing production of sewage sludge from wastewater treatment plants has raised critical questions regarding the most efficient environmental and economic methods of managing the final product [4]. Europe produces an average of 13 million tonnes of sludge dry solids annually, while its main disposal routes are $54 \%$ land application, $12 \%$ is discharged into landfilling, $10 \%$ into other use and $24 \%$ is incinerated [5].

\subsection{Sewage sludge ash}

It is estimated that approximately 1.7 million tonnes of SSA are produced annually worldwide and is likely to increase in the future [6]. It is also estimated that in the near future up to $40 \%$ of sewage sludge will be incinerated to be used as an additive in production of lightweight aggregates, mortars, concrete, clay brick, asphalt paving mixes, ceramic tiles, eco-cement and as a soil conditioner mixed with lime and sewage sludge [7]. 


\subsection{Incineration process}

Incineration of sewage sludge ash must be optimized at $800^{\circ} \mathrm{C}$ to preserve the pozzolanic activity of the resultant ash. The specific size range and properties of the sludge ash depend to a great extent on the type of incineration system and the chemical additives introduced in the wastewater treatment process [8]. The chemical components of SSA show the presence of a high amount of $\mathrm{SiO} 2, \mathrm{CaO}, \mathrm{Al} 2 \mathrm{O} 3$, and $\mathrm{Fe} 2 \mathrm{O} 3$, confirming it to be a good pozzolanic material [9].

\subsection{Attica sewage}

The Attica Basin occupies an area of approximately 3,808 square kilometres and covers $2.9 \%$ of the total area of the country. The total length of the sewage disposal system in the Attica Basin is roughly $6,000 \mathrm{~km}$ and the total area of the sewage system's drainage basin is roughly 50,000 hectares [10]. Apart from urban sewage and a limited amount of rainwater, the sewage network also carries pre-processed liquid waste from manufacturing plants. These are separated through separation chambers, and together end up in wastewater treatment plants.

\subsection{Wastewater treatment plants}

Greece produces an average of 300,000 tonnes of sludge dry solids annually. The Metamorfosis WWTP, the Thriassio Pedio WWTP and the Psyttalia WWTP are the main wastewater treatment plants in the greater Attica Basin. The latter's sludge drying unit final product (120-150 tonnes per day with approximately $92 \%$ dry solids) is a renewable energy source and is utilized as secondary fuel in cement factories and power stations [11].

\section{LOCAL SCALE}

Earthwood project is located in Salamis; an island in the Saronic Gulf in Greece, close to Piraeus Port to the west of Athens. Salamis has 40,000 permanent residents and comprises an area of 9,609 hectares. Its geopolitical location is of strategic significance and is historically connected with the naval battle of Salamis (480 BCE), as one of the most important historical events in early Greek antiquity and Western civilization.

\subsection{Compositional principles}

\subsubsection{Fertile ground}

The plot is divided into a grid of four equal zones running NE-SW, and a grid of two zones whose ratio to each other is 2:3, running NW-SE. The zones in these two directions have a specific function which in the first zone group is described as "threshold", "house",

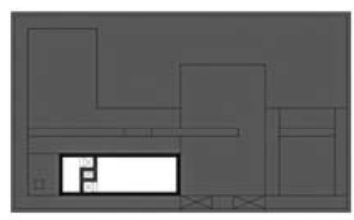

Underground Plan

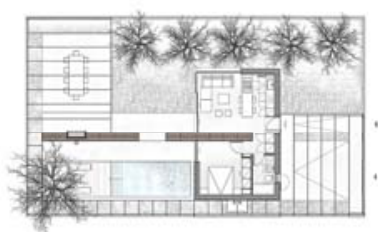

Groundfloor Pian

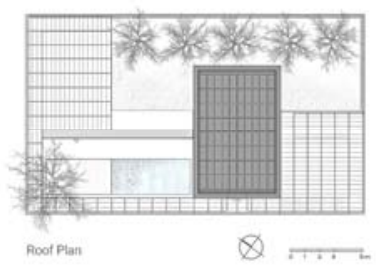

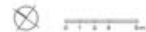

Figure 1: Plans. (Source: Kitriniaris, 2018.) 
"interspace", "courtyard" and in the second zone group as "private" and "public". The zones of each group organize the territory regarding the main sustainability principles.

\subsubsection{Rammed earth wall}

The reinforced rammed earth wall is located at the point of intersection of the public and private spaces, thus functioning as a perceptible boundary between the two areas. The wall is constructed from rammed earth, is fully recyclable, does not emit fumes or toxic substances, and it is also highly fire resistant. Lastly, it maintains humidity levels at an ideal percentage for human habitation, enhancing the microclimate and improving living conditions.

\subsubsection{Wood house}

The house is articulated between the "threshold" and the "interspace" zones, maintaining a part of the rammed earth wall within its interior. The wall element divides the public spaces; the kitchen and the living room, from the private ones; the bedroom and the bathroom. The sustainable residence is energy self-efficient and is fully reversible as it is constructed from structural Cross Laminated Timber Panels which are fabricated by local industries.

\subsubsection{Green canopy}

The main intention is to create a spatial grid to support climbing plants, thus simultaneously creating spaces that are shaded from solar radiation, especially during the summer months. In addition, planting evergreen trees along the northwestern border functions as a vegetative filter that will not only mute the noise pollution from the public road, but also reduce the intensity of northern winds towards the yards and the house.

\subsection{Renewable energy sources and water management}

\subsubsection{Bioclimatic principles}

Earthwood integrates advanced energy and water utilization processes regarding its bioclimatic operation. The main house opening follows the East axis with the intention of creating a protective shell against the southerly sun, especially during the summer months; the roof is angled by $10 \%$ for the better performance of the photovoltaic panels, while the water surface enhances the microclimate.

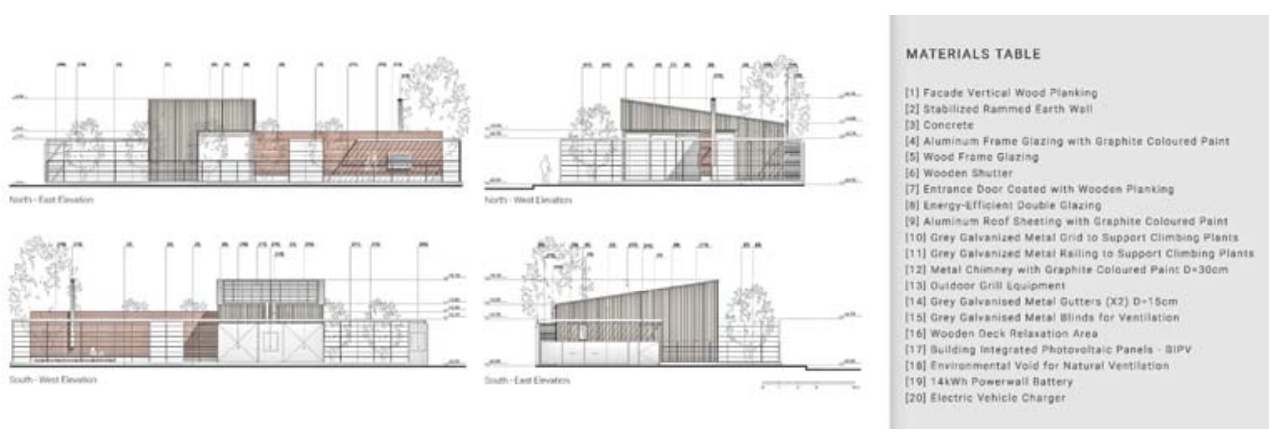

Figure 2: Elevations. (Source: Kitriniaris, 2018.) 

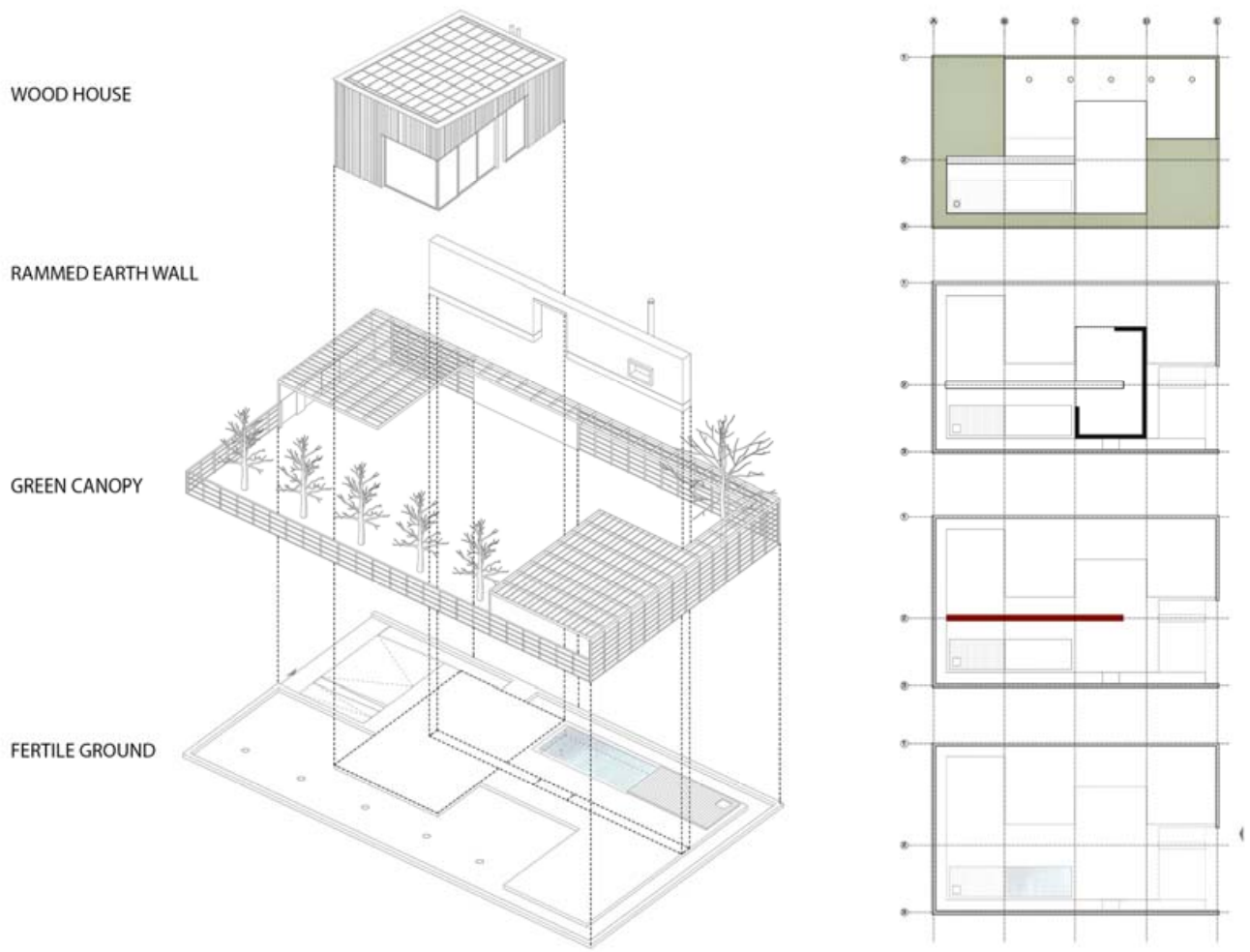

Figure 3: Compositional exploded analysis diagram. (Source: Kitriniaris, 2018.)

\subsubsection{Solar energy}

The energy autonomy of the house is achieved with the installation of integrated photovoltaic panels (BIPV) on the 10 degrees pitched roof which are connected with a $14 \mathrm{kWh}$ Powerwall battery. The house consumes an average of $1.2 \mathrm{kWh} /$ day when populated by 4 residents. The stored electrical power is also used to heat water for household usage and for heat convection through water pipes integrated inside the rammed earth wall.

\subsubsection{Water management}

Bearing in mind the annual rainfall data for the Attica Basin, two water reservoirs with a total capacity of $86.80 \mathrm{~m}^{3}$ are created to collect rainwater from the specially designed surfaces and roof, and recycle it either for household use or for irrigation. Water recycling is achieved after treatment processes with sand-filters and disinfection systems powered by the stored solar energy.

\subsubsection{Green canopy}

The spatial grid supports climbing plants, thus simultaneously enhancing user experience by creating graduated qualities of outdoor space. The choice of deciduous vegetation forms courtyards that are shaded from solar radiation during the summer months and warmed during the winter. Last but not least, planting evergreen trees along the northwestern border reduce the intensity of northern winds. 

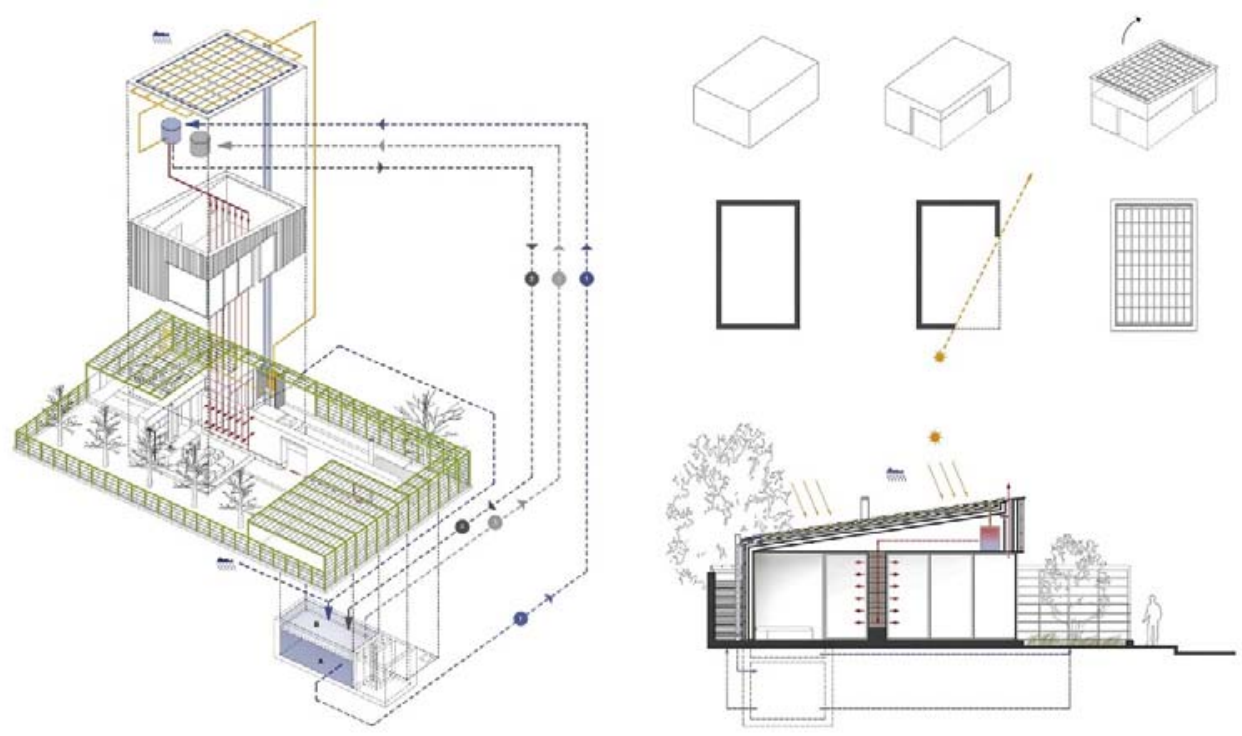

Figure 4: Axonometric exploded diagram - bioclimatic section and energy circulation process. (Source: Kitriniaris, 2018.)

\subsection{Rammed earth wall}

\subsubsection{Stabilization process}

The use of SSA as a rammed earth stabilizer mixed with cement or lime aims to enhance the pozzolanic properties of the loam [12]. This is to increase the strength and cohesion of the soil, to reduce shrinkage and swelling, to create a waterproof layer so that it is less permeable by moisture, and resistant to weather conditions. The mixture of SSA with cement or lime at a ratio of $1: 1$ by weight shows better stabilization results.

\subsubsection{Objective}

The objective regarding the Rammed Earth wall stabilization, concerns laboratory examination of the behaviour of the loam, in the specific environment, or in a possible seismic reaction. For this purpose, samples of earth were taken from the site with the aim of creating different specimens containing varying proportions of 5\%,10\% and $15 \%$ SSA mixed with $5 \%$ cement or $5 \%$ lime in addition to loam. The S-C-H (Calcium Silicate Hydrate), binds the soil particles and increases the compressive and flexural strength [13].

\subsubsection{Methodology}

The methodology focuses on the effect of SSA varying proportions on specific properties of the natural soil mixed with cement or lime. The elements examined are: geotechnical properties, including grain size distribution, plastic index, shrinkage, swelling, dry density and moisture content, the Unconfined Compressive Strength (UCS) and Cube Compressive Strength as well as the Weathering Effect or spay test [14]. 


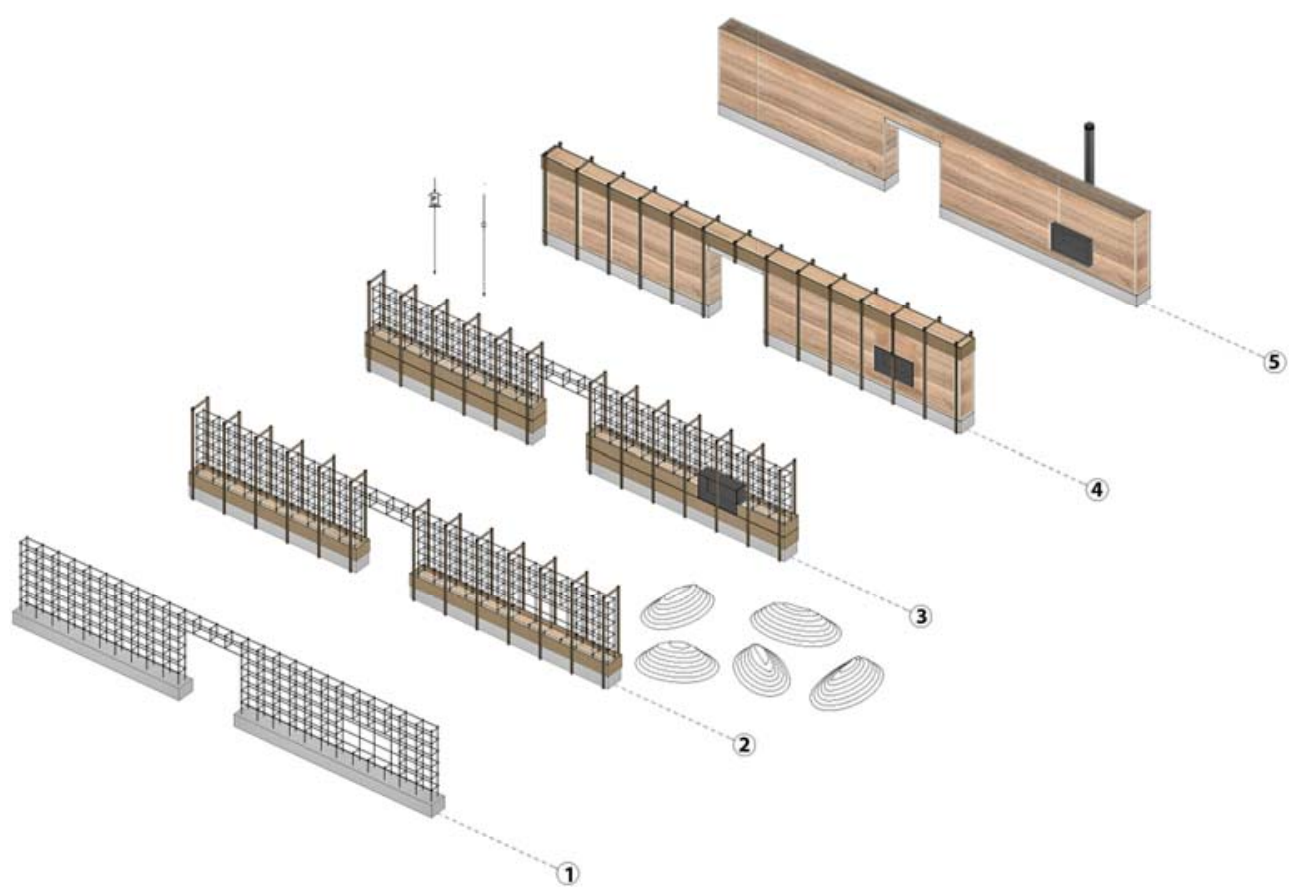

Figure 5: Rammed earth wall construction process. (Source: Kitriniaris, 2018.)

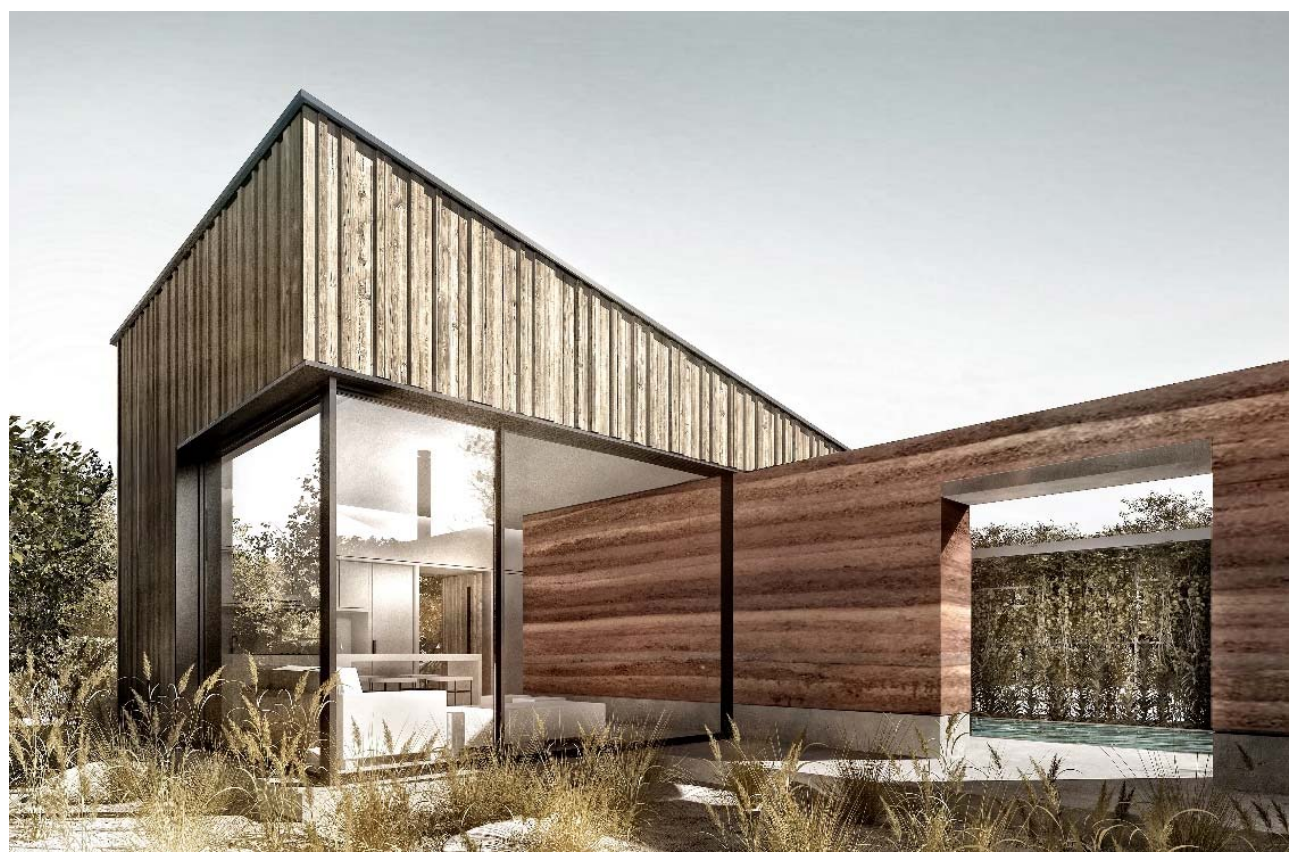

Figure 6: The rammed earth wall penetrates the wood house. (Source: Kitriniaris, 2018.) 


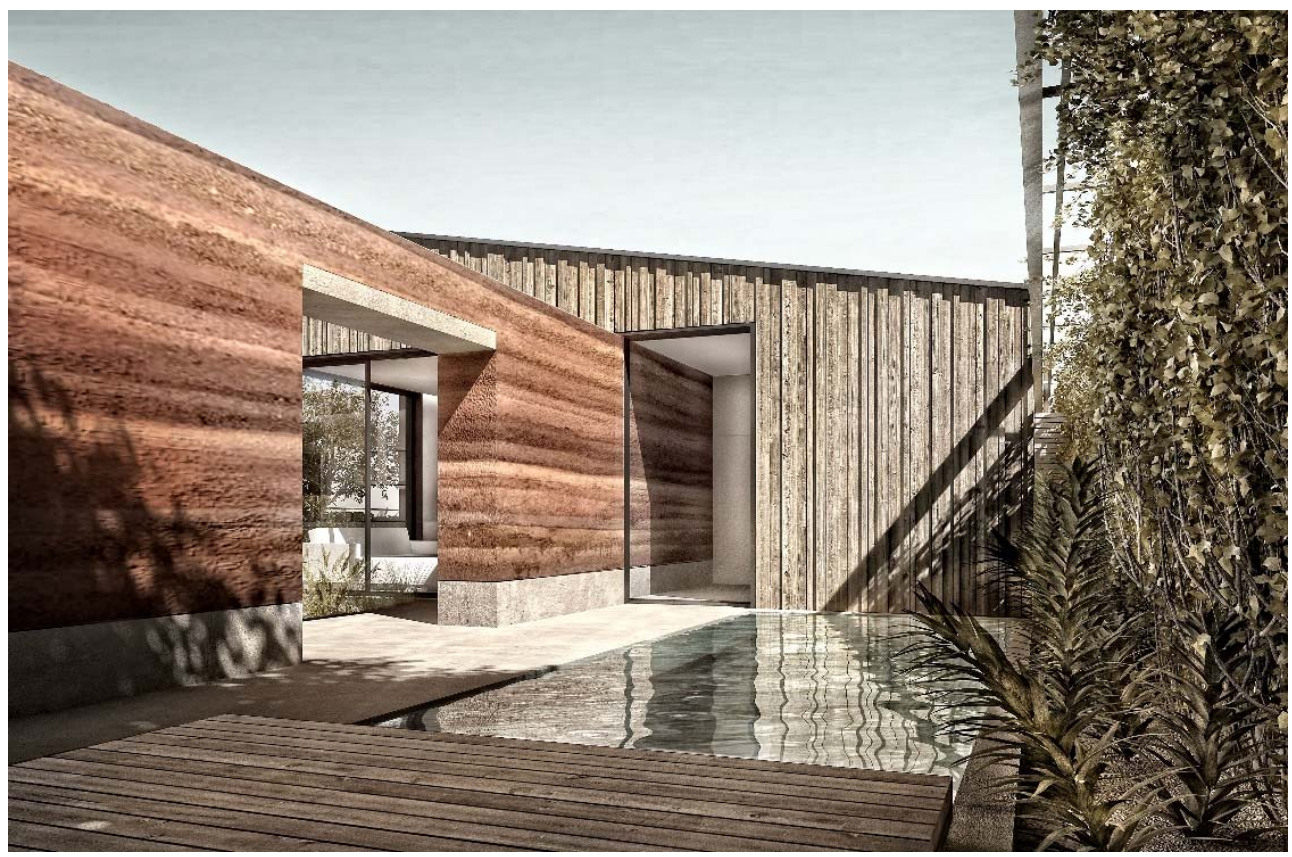

Figure 7: The rammed earth wall together with the water surface enhance the microclimate. (Source: Kitriniaris, 2018.)

\subsubsection{Properties}

Sewage Sludge Ash is a silty-sandy material [15]. A relatively large fraction of the particles (up to $90 \%$ in some ashes) are less than $0.075 \mathrm{~mm}$ (No. 200 sieve) in size. The $\mathrm{pH}$ of SSA can vary between values 6 and 12, but it is generally alkaline. Even though SSA has a relatively low phosphorus proportion as well as low moisture, and low organic content in comparison to natural soil, the earth as a construction material should be free from organic matter. So, specific measures should be taken regarding the wastewater treatment physiochemical processes (BOD-COD) [16].

\subsubsection{Construction}

The Rammed Earth construction process takes place in situ with the use of a sliding formwork. The layers of moist earth, i.e. a mixture of clay, silt, sand, gravel, a $5 \%$ proportion of SSA, and a 5\% proportion of cement or lime are added and compressed with mechanical or manual compacting equipment. The construction is finished when the sliding formwork is removed leaving visible layers of compacted earth [17].

\subsection{Construction process}

\subsubsection{Fabrication}

Fabrication is expected to be undertaken by local industries in order to support the local economy and create jobs for the regional community. 


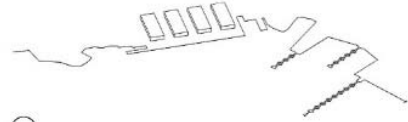

(1)

(4)

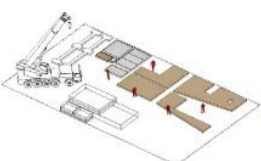

(2)

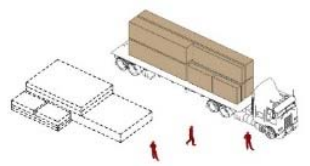

(5)

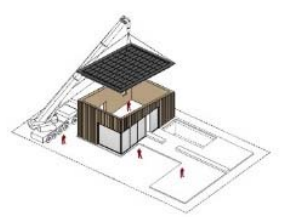

(3)

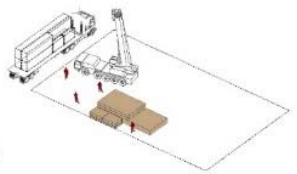

Figure 8: Construction process diagram. (Source: Kitriniaris, 2018.)

\subsubsection{Packaging}

The CLT panels and additional construction materials are flat packed and delivered on site. Each assembly box contains a complete house unit.

\subsubsection{Delivery}

The flat pack is transported to the site by truck and shipped directly from Piraeus port. Assembly boxes are unloaded on site by crane.

\subsubsection{Unpacking and storage}

The materials, joints and extra components are stored under a temporary structure to control environmental conditions.

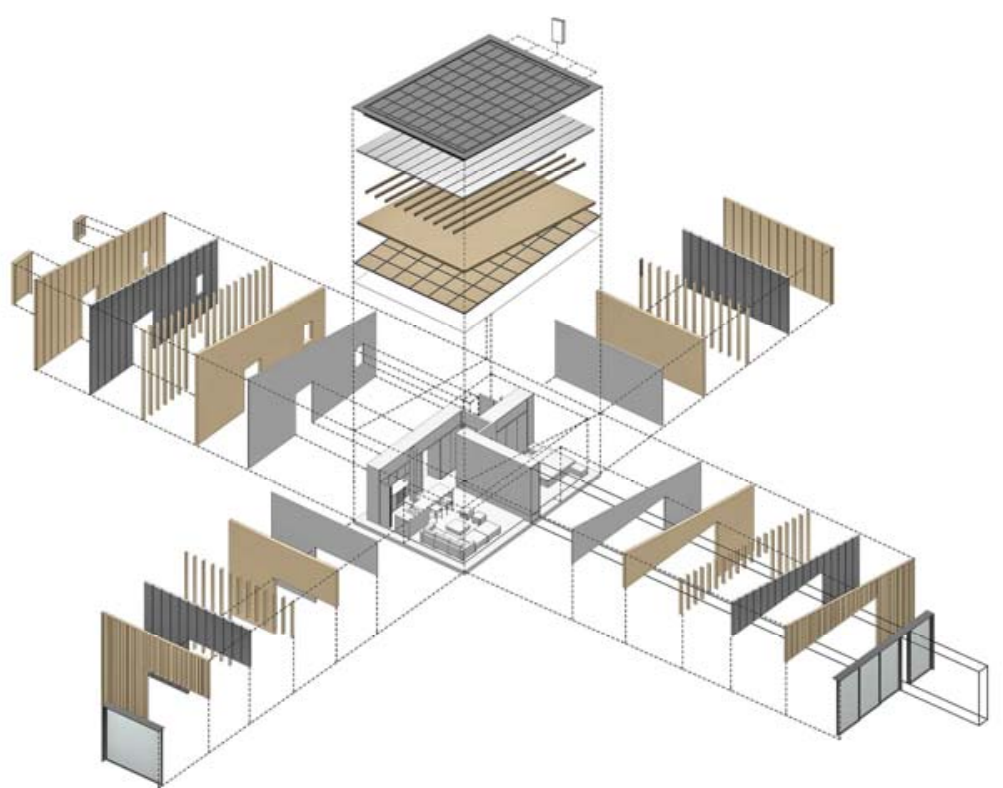

Figure 9: Axonometric construction analysis. (Source: Kitriniaris, 2018.) 


\subsubsection{Construction}

Each element is placed by crane. Assembly is completed in covered sealed conditions within $2-4$ days by a local crew [18].

\section{SUSTAINABILITY TARGETS}

5.1 Earthwood is integrated into a wider economic framework for sustainable construction

1. Contributes to circular economy by reducing sewage sludge disposal costs likely to rise due to rising landfill charges, by minimizing infrastructure and operation costs and by avoiding wasteful consumption of material resources.

2. Promotes the conservation of the environment by adopting cradle to cradle regenerative design processes, by using sewage sludge as secondary fuel in cement factories and by reducing the greenhouse gases including $\mathrm{CO} 2, \mathrm{SO} 2$ and $\mathrm{NOx}$, over the lifecycle of manufacturing.

3. Offers advancements in the disciplines of architecture and environmental engineering, by improving the quality of conventional construction materials.

4. Increases public awareness about waste disposal methods and highlights the benefits of recycling.

5.2 Earthwood uses renewable energy sources and natural recyclable construction materials

1. Minimizes its ecological footprint while maximizing its positive impact on the environment by using renewable energy sources including Building Integrated Photovoltaic Panels and sound water utilization technologies including reservoirs for water recycling.

2. Integrates sustainable construction technology with traditional building methods by using structural cross laminated timber as recyclable construction material and sewage sludge ash as rammed earth stabilizer mixed with cement or lime in addition to locally-sourced loam.

3. Supports the local economy by creating jobs for the regional community, as the fabrication of CLT panels is undertaken by local wood industries.

4. Enhances the participation of locals in the rammed earth construction process.

5.3 Earthwood promotes social inclusion as a pilot project to shelter migrating populations

1. Contributes to the formation of a socially viable environment, by promoting social inclusion of migrating populations into the urban fabric, as well as by enhancing shared values through social integration and material expression.

2. Offers an architectural experience enhanced by the tactility of materials i.e. the timber and rammed earth structure as well as by the light and shadow effects produced from the green canopy during the daytime, with the aim of strengthening the sense of place between different civilizations.

3. Generates an acceptable rate of return and covers the operating costs over its lifetime.

4. Ensure an enduring positive impact on communities by enhancing social responsibility and economic viability. 


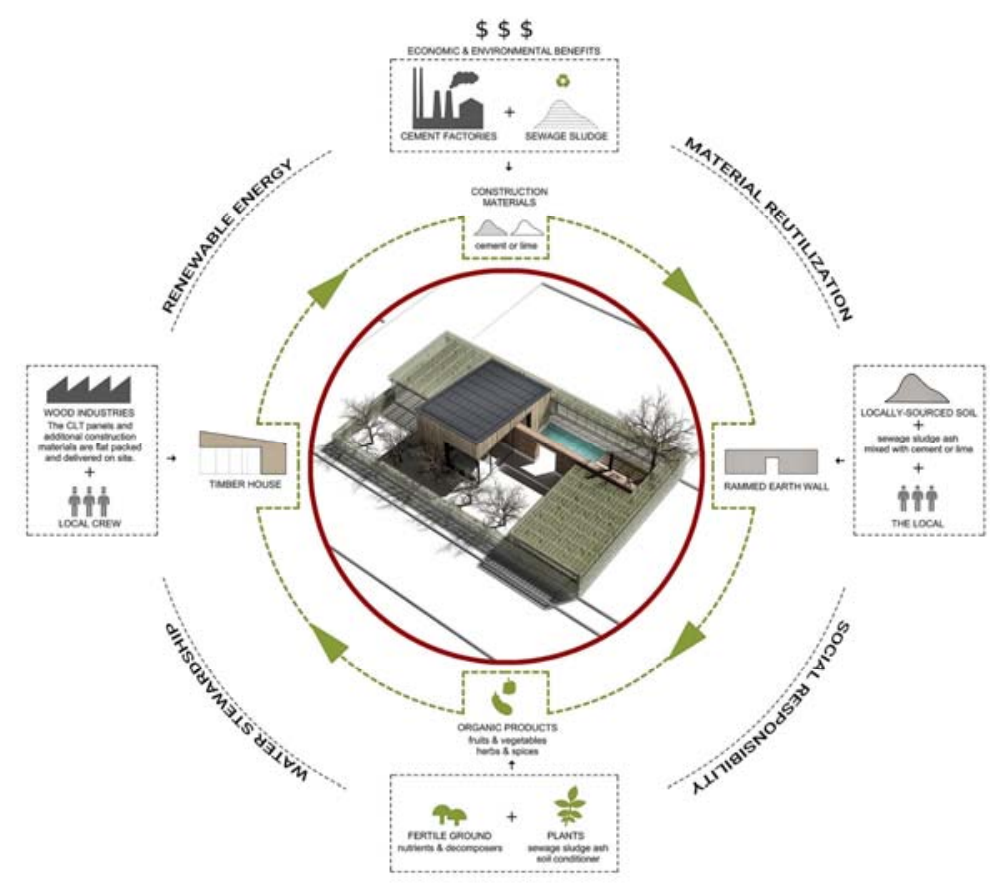

Figure 10: From circular economy to sustainable construction. (Source: Kitriniaris, 2018.)

\section{REFERENCES}

[1] Population Growth, Online. https://ourworldindata.org/world-population-growth. Accessed on: 5 Jun. 2018.

[2] Cradle to cradle production model, Online. https://en.wikipedia.org/wiki/Cradle-tocradle_design 23123123. Accessed on: 5 Jun. 2018.

[3] Circular economy, Online. http://ec.europa.eu/environment/circular-economy/ index_en.htm. Accessed on: 5 Jun. 2018.

[4] Alario, J., Post, C. \& Bianchi, M., EIB financing of solid waste management projects, Evaluation Report, June 2002.

[5] Ødegaard, H., Paulsrud, B. \& Karlsson, I., Wastewater sludge as a resource: Sludge disposal strategies and corresponding treatment technologies aimed at sustainable handling of wastewater sludge. Water Science and Technology, 46(10), pp. 295-303, 2002. DOI: 10.2166/wst.2002.0358.

[6] Foisy, B.F., Ramon L.I., Chattopadhyay, A. \& Karell, M., Sewage sludge incineration: Meeting air emissions in the nineties and beyond. Proceedings of the National Waste Processing Conference, ASME, 1994.

[7] Bhatty, J.I. \& Reid, K.J., Lightweight aggregates from incinerated sludge ash. Waste Management \& Research, 7(4), 363-376, 1989a. DOI: 10.1016/0734-242x(89) 90073-6.

[8] Gray, D.H. \& Penessis, C., Engineering properties of sludge ash. Journal of Water Pollution Control Federation, 44(5), 1972. 
[9] Cyr, M., Coutand, M. \& Clastres, P., Technological and environmental behavior of sewage sludge ash (SSA) in cement-based materials. Cement and Concrete Research, 37(8), pp. 1278-1289, 2007. DOI: 10.1016/j.cemconres.2007.04.003.

[10] Eydap, S.A., Athens Water Supply and Sewerage Company, Online. www.eydap.gr/ en/TheCompany/DrainageAndSewerage/NetworkFuctionality/. Accessed on: 5 Jun. 2018.

[11] Sewage \& Wastewater Treatment: Psyttalia, Akrokeramos, Thriasio Pedio, Meatamorfosis, Online. www.eydap.gr/en/TheCompany/DrainageAndSewerage/ Sewerage/. Accessed on: 5 Jun. 2018.

[12] Prasanna Kumar, P., Stabilised Rammed Earth for Walls: Materials, Compressive Strength and Elastic Properties, Department of Civil Engineering, IISc: Bangalore, 2009.

[13] Ping, Y., Kirkpatrick, R.J., Brent, P., McMillan, P.F. \& Cong, X., Structure of calcium silicate hydrate (C-S-H): near-, mid-, and far-infrared spectroscopy. Journal of the American Ceramic Society, 82(3), pp. 742-748, 1999.

[14] Walker, P., Keable, R., Martin, J. \& Maniatidis, V., Rammed Earth Design and Construction Guidelines, BRE Bookshop Publications, 2005.

[15] Pan, S.C., Tseng, D.H. \& Lee, C., Use of sewage sludge ash as fine aggregate and pozzolan in Portland cement mortar. Journal of Solid Waste Technology and Management, 28(3), pp. 121-130, 2002.

[16] Clescerl, L.S., Greenberg, A.E. \& Eaton, A.D., Standard Methods for Examination of Water and Wastewater, American Public Health Association: Washington, DC, 20th ed., 1987.

[17] Minke, G., Building with Earth, 3rd ed., Birkhäuser: Basel, 2012.

[18] The American Institute of Timber Construction, (AITC), Timber Construction Manual, ed. J. Linville, John Willey \& Sons, 2012. 